\title{
Snapshot of photovoltaics - March 2021
}

\author{
Arnulf Jäger-Waldau* \\ European Commission, Joint Research Centre (JRC), Via E. Fermi 2749, Ispra, VA I-21027, Italy
}

Received: 19 March 2021 / Received in final form: 6 April 2021 / Accepted: 8 April 2021

\begin{abstract}
For the past 10 years, photovoltaic electricity generation has been the fastest-growing power generation source worldwide. It took almost six decades to achieve $100 \mathrm{GW}$ of solar energy capacity in 2012 , but the 1 TW barrier is likely to be broken during 2022. Despite the ongoing COVID-19 pandemic, the overall investments in solar energy have increased by $12 \%$ to USD 148.6 billion (EUR 125 billion). In 2020, more than $135 \mathrm{GW}$ of new solar photovoltaic electricity generation capacity was installed. The recovery of China, the continuous growths in Europe and the USA as well as new emerging markets were the main drivers. The number of countries installing more than $1 \mathrm{GW}$ annually has increased to 18 in 2020 . The continuation of price reductions in the battery storage sector has again resulted in a growing market for local battery storage systems in solar farms as well as decentralised photovoltaic electricity generation systems. Apart from classic electricity use, renewable electricity for the generation of green hydrogen will become more and more important in the future.
\end{abstract}

Keywords: Renewable energies / photovoltaic / green hydrogen / energy challenge / policy options / technological development / market development

\section{Introduction}

After the 25th session of the Conference of the Parties (COP25) in Madrid, Spain, in December 2019 failed to reach an agreement on the urgent pathways to decarbonise the world's energy supply by 2050 , the attention shifted to COP26 in Glasgow, UK, in November 2020. However, due to the ongoing COVD-19 pandemic, the meeting was postponed to November 2021 and no international agreement has yet been reached.

When the International Energy Agency (IEA) launched its latest World Energy Outlook Report (WEO 2020) in October 2020, one of the headlines read "Solar becomes the new king of electricity..." [1,2]. Another key message linked to the COVID-19 effect indicates thatglobal energy demand would drop by $5 \%$, energy related CO2 emissions by $7 \%$ and overall energy investments by $18 \%$. Of all the presented pathways, only the "Net Zero Emissions by 2050" scenario is in line with the Paris Agreement. The crucial timespan to achieve globally $40 \%$ greenhouse gas (GHG) emissions reduction by 2030 starts now. To achieve this goal, renewable sources must provide $60 \%$ of the global electricity generation, which is more than doublethe

\footnotetext{
* e-mail: arnulf.jaeger-waldau@ec.europa.eu
}

percentage in $2019(27 \%)$, and rising in terms of total electricity generation, as the latterwill increase from 26942 TWh in 2019 to 34123 TWh in 2030. This scenario requires an increase inrenewable electricity generation from 7274 to $20474 \mathrm{Wh}$ within the same timeframe.

One of the key technology options, apt for scalability in a short period of time, is solar photovoltaics (PV), which can be deployed in a modular way almost everywhere on this planet. Solar resources across the world are abundant and cannot be monopolised by one country.

According to the "Net Zero Emissions by 2050" scenario of the WEO 2020, the worldwide installed PV capacity would need to increase to $1840 \mathrm{GW}^{1}$ by 2025 and 3929 GW by 2030. In such a scenario solar photovoltaic electricity would account for about 5420 TWh or $15.9 \%$ of the worldwide energy supply. This quantity is almost double the amount modelled in the "Stated Policies Scenario" with 2764 TWh. However, even the "Net Zero Emissions by 2050" scenario still falls short compared to more ambitious scenarios, which call for $100 \%$ renewable electricity or even a $100 \%$ renewable energy supply by 2050 [3-5].

\footnotetext{
${ }^{1}$ The capacity numbers in this paper are the nominal capacity Wp or DC. If AC numbers are used it is indicated.
} which permits unrestricted use, distribution, and reproduction in any medium, provided the original work is properly cited. 


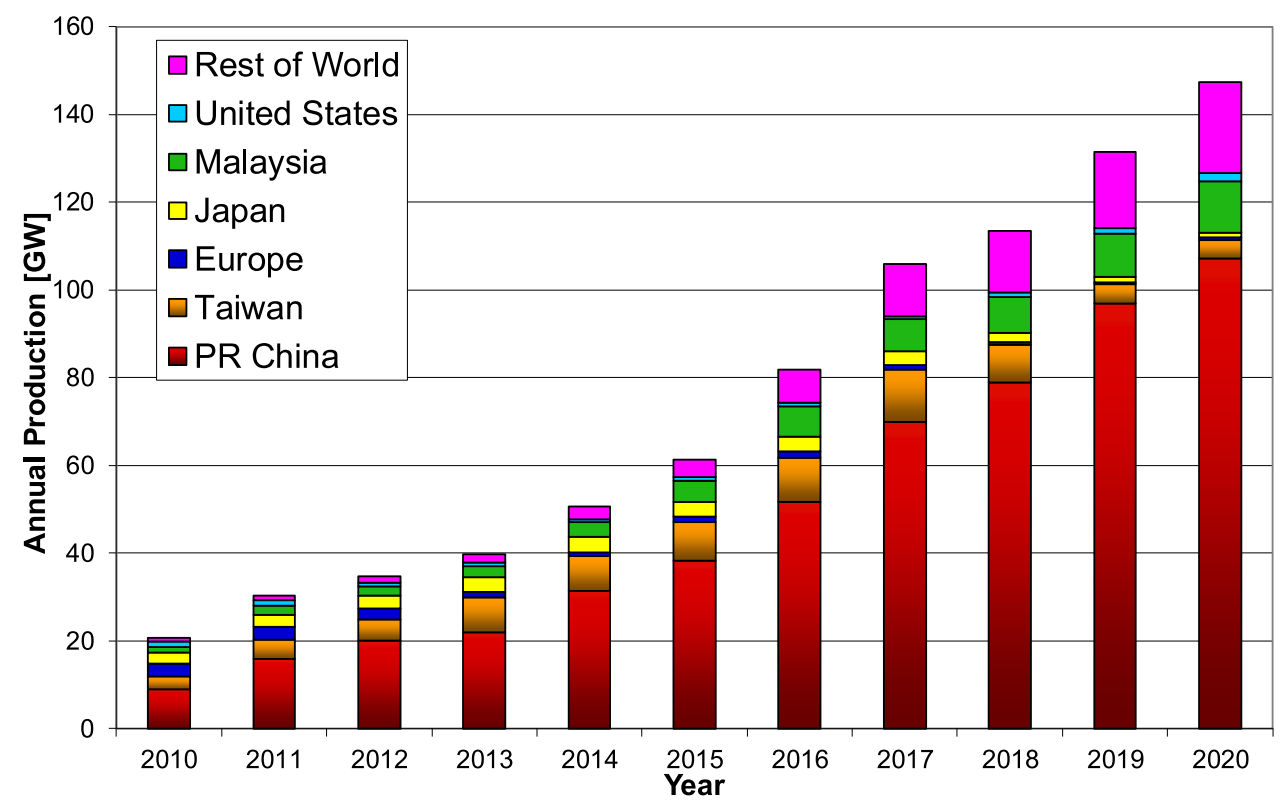

Fig. 1. World PV cell/thin film module production from 2010 to 2020.

\section{PV solar cell production}

In 2020, the production data for the global cell production ${ }^{2}$ varied between 140 and $160 \mathrm{GW}$ and could exceed $200 \mathrm{GW}$ in 2021. The significant uncertainty in this data is due to the highly competitive market environment, as well as the fact that some companies report shipment figures, some report sales, while others report production figures. A detailed description of the uncertainties in production and deployment statistics has already been published in earlier versions of this report [6].

The data presented, collected from stock market reports of listed companies, market reports and colleagues, were then compared to various data sources, which led to an estimate of $147 \mathrm{GW}$ (Fig. 1), representing an increase of about $12 \%$ compared to 2019 .

Over the past decade, solar system hardware has seen a steep price decline, which, coupled with fierce competition amongst the manufacturing companies along the solar value chain, resulted in an ongoing consolidation in the solar industry. At the beginning of 2021, Bloomberg New Energy Finance reported that they tracked more than 700 companies along the crystalline silicon value chain i.e. polysilicon, wafer, solar cells and module manufacturing [7]. Due to the plant complexity and technological challenges, polysilicon and wafer factories have the highest investment costs as wellas the longest construction time. Therefore, the consolidation in these two value chain

\footnotetext{
${ }^{2}$ Solar cell production capacities mean:

- In the case of wafer silicon based solar cells, only the cells

- In the case of thin-films, the complete integrated module

- Only those companies which actually produce the active circuit (solar cell) are counted

- Companies which purchase these circuits and make cells are not counted.
}

segments is the highest. On the other hand, new factories are more competitive due to lower production costs. Solar cell and module manufacturing plants are more modular and can be built faster, thus offering more flexibility to react to technology progress or impacts of policy decisions, like local content rules and import tariffs.

Another interesting fact is that about $90 \%$ of new polysilicon capacities as well astwo-thirds of the current manufacturing capacity for silicon modules, which surpasses $250 \mathrm{GW}$, were only commissioned after 2017 [7].

In order to realise any of the various scenarios to limit global warming to $1.5^{\circ} \mathrm{C}$, as pledged in the Paris Agreement, the scale-up of renewable energy deployment and acceleration of the energy system decarbonisation over the next decade is crucial. The annual increase in manufacturing output required depends on the ambition of the scenario. An increase from almost $150 \mathrm{GW}$ in 2020 to about $550 \mathrm{GW}$ would be necessary for the WEO 2020 scenario or above $2.5 \mathrm{TW}$ for a $100 \%$ renewable energy scenario. This huge challenge raisesthe question of whether PV technology and the industry are ready for it.

In the past decade, the global production of the solar photovoltaic manufacturing industry has increased from 21 GW in 2010 to almost $150 \mathrm{GW}$ in 2020 with a compound annual growth rate (CAGR) of more than $21 \%$. A continuation of this trend, which is technologically feasible, would lead to an annual production of over $1 \mathrm{TW}$ in 2030 [8-10]. To reach the $100 \%$ renewable energy benchmark of $2.5 \mathrm{TW}$, annual production CAGR would have to increase to $33 \%$.

\section{Solar PV electricity generation and markets}

Over the past few years, the CAPEX for PV solar systems have converged globally. However, differences in market 


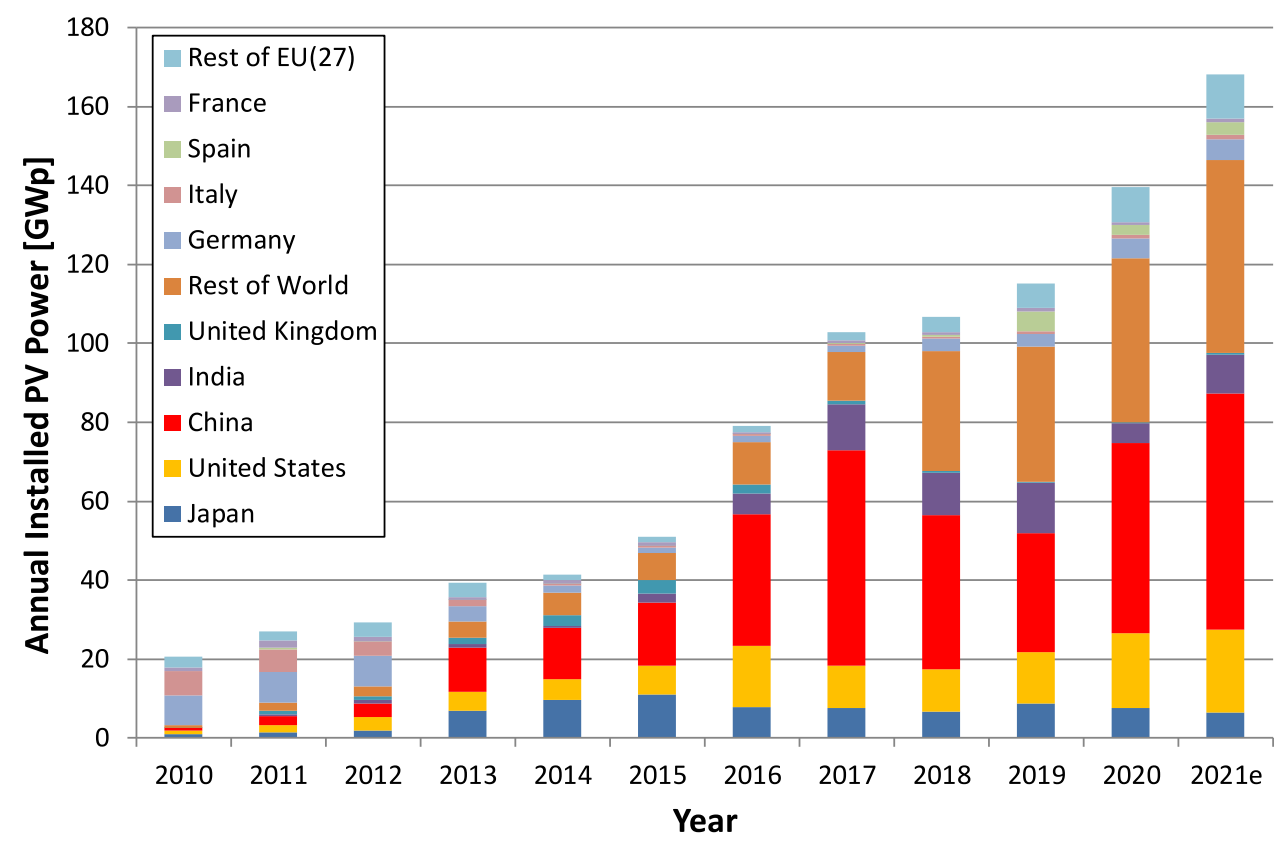

Fig. 2. Annual photovoltaic installations from 2010 to 2020 with estimate for 2021 (data source: [18-21] and own analysis).

size and local competition can still lead to significant variations. Factors like import taxes, local content rules or existing tax credits have an additional influence on local prices. A global benchmark for the levelised cost of electricity (LCOE) is published regularly by BNEF. In the 2nd half (H2) of 2020, this benchmark for utility scale PV systems was USD 47 per MWh for non-tracking and USD 39 per MWh for tracking systems [11].

In the past 10 years, lithium-ion battery packs have shown a learning rate of $18 \%$ and a price decreased of $89 \%$. The corresponding levelised cost of electricity storage (LCOES) for battery systems ranges between USD 120 and 143 per MWh for a 4-h storage system and between USD 167 and 193 per MWh for a 1-h storage system. The short time $(1 \mathrm{~h})$ battery storage systems are most suited to provide balancing services as well as capacity. Their role can be compared to open-cycle gas turbines, which run infrequently for a maximum of $1 \mathrm{~h}$ per day. On the other hand a $4 \mathrm{~h}$ storage runs on a daily cycle providing electricity during times when the PV system is not generating. There are indications that the LCOES can be even lower with a $6 \mathrm{~h}$ storage system [12].

This price development as well as various incentive programmes have increased the number of residential and commercial PV projects with storage. In large scale PV plants the addition of storage is mainly driven by the goal to utilise the $\mathrm{AC}$ connection as efficiently as possible. In 2020 about $4.5 \mathrm{GW}$ of new energy storage capacity was added and 2021 predictions point to a range of $10 \mathrm{GW}$ [13].

Compared to the benchmark LCOE mentioned before, the local electricity generation costs from photovoltaic systemsare determined by a number of additional factors. Geographical and technology factors like solar radiation, tracking or no-tracking PV system design, string or central inverter configuration, fixed operation and maintenance $(\mathrm{O} \& \mathrm{M})$ as well as connection costs are important.
However, one of the most relevant factors is the financial aspect of a project [14]. The share between debt and equity as well as interest rates and return on equity expectations has great influence and can differ substantially from country to country.

Despite the ongoing COVID-19 pandemic, global investments in renewable energy slightly increased by $2 \%$ to USD 303.5 billion [15]. Investments into new solar capacity increased by $12 \%$, reaching USD 148.6 billion. Preliminary data show that the new PV capacity increased by about $20 \%$ to almost $140 \mathrm{GW}$ in 2020 (Fig. 2), which is towards the upper end of the conservative and optimistic forecasts [16,17]. For 2021, market forecasts are considerably higher, which would bring the total cumulative installed PV capacity to more than 900 GW (Fig. 3). It should be noted that some optimistic scenarios forecast capacity additions of $200 \mathrm{GW}$ or more.

China currently has a cumulative installed capacity of more than $250 \mathrm{GW}$, representing roughly one third of the total global $775 \mathrm{GW}$ installed PV capacity. The European Union (EU27) follows with about $18 \%$ or $138 \mathrm{GW}$ and the USA with almost $95 \mathrm{GW}$ (Fig. 3).

\subsection{Africa}

During the past decade, the total installed solar PV capacity has increased by two orders of magnitude from about $110 \mathrm{MW}$ in 2010 to $12 \mathrm{GW}$ at the end of 2020 . The main drivers for this growth were Algeria, Egypt, Morocco and South Africa, which now account for roughly $60 \%$ of the total capacity. The continent has vast solar resources but hydropower is still the largest source of renewable electricity generation, with hydro dams supplying $17 \%$ of the demand. However, water scarcity and climate change could hamper future expansion. In a recent study, floating $\mathrm{PV}$ was presented as a potential alternative to expand the 


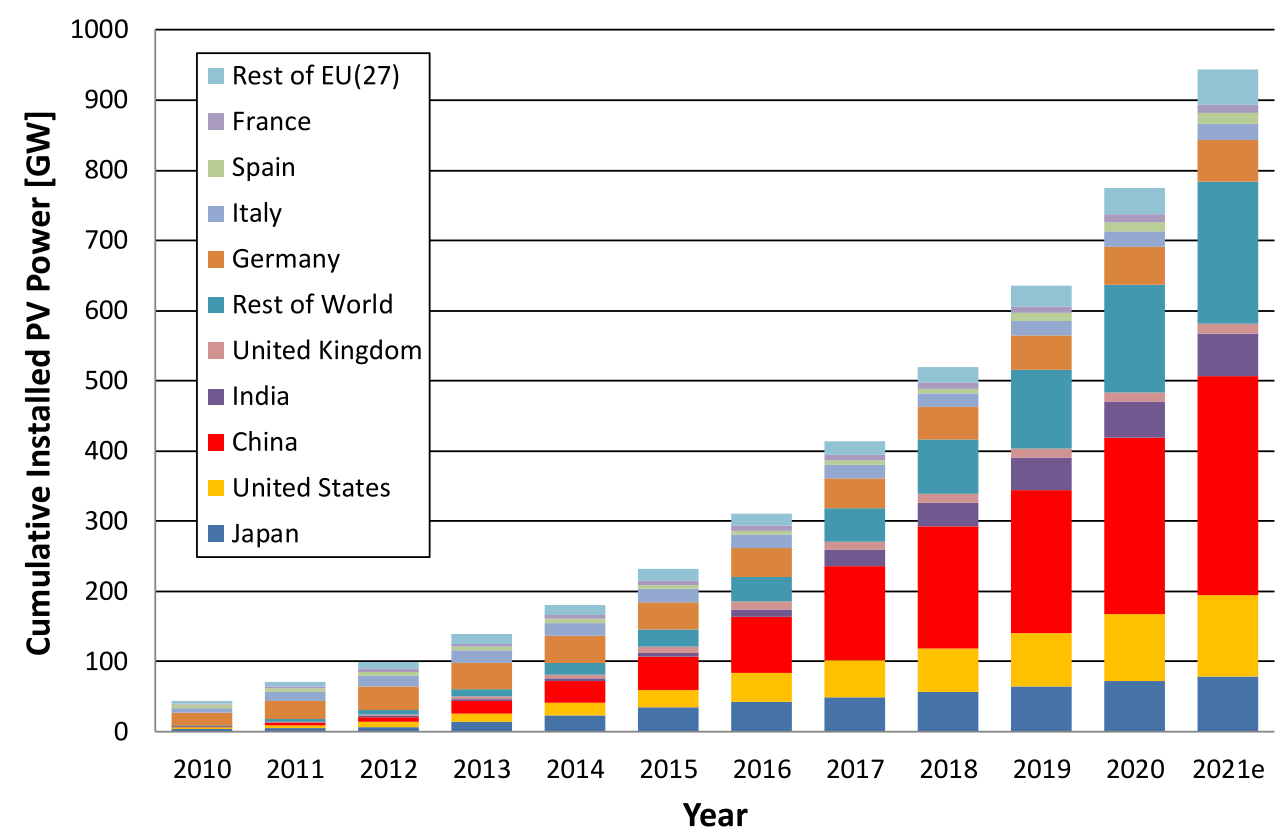

Fig. 3. Cumulative photovoltaic installations from 2010 to 2020 with estimate for 2021 (data source: [18-21] and own analysis).

electricity generation of hydro dam plants [22]. Covering just $1 \%$ of the total surface of existing reservoirs could increase the total electricity output of these plants by $50 \%$.

An important tool to finance large solar PV projects in Africa is the World Bank's Scaling Solar programme [23]. So far, six African Nations, Côte d'Ivoire, Ethiopia, Madagascar, Senegal, Togo and Zambia have signed financing agreements.

In 2018 the Africa Development Bank (AfDB) launched an initiative called "Desert to Power", which aims to deploy $10 \mathrm{GW}$ solar power for the 250 million people across the Sahel zone. On 16 September 2019, on the occasion of the G5 Sahel summit in Ouagadougou, the heads of state gave strong support to this initiative. In December 2020, the AfDB released the first grants with a value of USD 6.5 million for projects in Chad, Burkina Faso, Niger, Mauritania and Mali through the Sustainable Energy Fund for Sustainable Africa (SEFA) [24].

With $2 \mathrm{GW}_{\mathrm{AC}}$ power, the Benban solar complex is currently the largest solar project in Africa, located near Aswan in upper Egypt. The Benban project consists of 41 individual plants, of which 31 have a $50 \mathrm{MW}_{\mathrm{AC}}\left(64 \mathrm{MW}_{\mathrm{DC}}\right)$ capacity each, whereas the remaining 10 projects have different capacities, due to the shape of the area [25].

\subsection{Americas}

Following a growth of more than $25 \%$ in the combined North and South American markets, new solar photovoltaic power capacity of about $27 \mathrm{GW}$ was added in 2020 . The three largest markets in 2020 were the USA (19 GW) Brazil (3.9 GW) and Mexico (1.5 GW). Currently, the Americas have an overall installed capacity of $120 \mathrm{GW}$, of which more than $75 \%$ is in the USA alone. For 2021, market forecasts indicate the possibility of reaching more than $30 \mathrm{GW}$.

\subsection{Asia \& pacific region}

In 2020, China installed more than $48 \mathrm{GW}$ of new solar photovoltaic power generation capacity, according to the New Energy Administration [26]. On the other hand, India experienced a strong decline in new installations to less than half the capacity installed in 2019. This development is mainly due to the widespread disruptions caused by the COVID-19 pandemic. Strong and stable markets in Australia, Japan, South Korea and Vietnam helped the Asian-Pacific PV market grow by $20 \%$ to $86.6 \mathrm{GW}$. For 2021 , a further $20 \%$ growth is possible, which would lift the annual market above the $100 \mathrm{GW}$ level.

\subsection{European Union}

Two major political events reshaped the renewable energy market in the European Union. The first was that the United Kingdom left the European Union on 31 January 2020, after 47 years of EU membership. The second was the announcement of the European Green Deal in December 2019, which was eventually adopted by the European Council in December 2020 [27].

In September 2020, the European Commission proposed to raise the 2030 climate targets, aiming at $55 \%$ GHG reductions by 2030 . The accompanying impact assessment [28] showed that such an increase in climate ambition is realistic and economically feasible. The 55\% GHG reductions target will require a share of renewable energy 
Table 1. World-wide scenarios of cumulative solar photovoltaic electrical capacities until 2040.

\begin{tabular}{|c|c|c|c|c|}
\hline Year & $2020(\mathrm{GW})$ & $2025(\mathrm{GW})$ & $2030(\mathrm{GW})$ & $2040(\mathrm{GW})$ \\
\hline Actual installations & 773 & & & \\
\hline Greenpeace (advanced $[\mathrm{r}]$ evolution scenario) & 844 & 2000 & 3725 & 6678 \\
\hline LUT 100\% RES Power 2017 & 1168 & 3513 & 6980 & 13805 \\
\hline LUT 100\% Energy 2019 & 1097 & 1628 & 12951 & 30531 \\
\hline BNEF NEO 2020 & 772 & 1534 & 2382 & 5009 \\
\hline IRENA 2019 reference case* & 514 & 1020 & 2017 & 3122 \\
\hline IRENA 2019 REmap case ${ }^{*}$ & 583 & 1358 & 3151 & 5761 \\
\hline IEA New Policy Scenario 2016 & 481 & 715 & 949 & 1405 \\
\hline IEA $450 \mathrm{ppm}$ Scenario $2016^{* *}$ & 517 & 814 & 1278 & 2108 \\
\hline IEA Stated Policy Scenario $2020^{* * *}$ & 687 & 1319 & 2019 & 3665 \\
\hline IEA Sustainable Development Scenario $2020^{* * * *}$ & 721 & 1774 & 3125 & 5891 \\
\hline
\end{tabular}

\footnotetext{
${ }^{*} 2020$ and 2025 values are interpolated, as only 2016, 2030 and 2040 values are given.

${ }^{* *} 2025$ value is interpolated, as only 2020,2030 and 2040 values are given.

${ }^{* * *} 2020$ value is interpolated, as only $2018,2025,2030$ and 2040 values are given.

${ }^{* * * *} 2020$ values are interpolated, as only $2019,2025,2030$ and 2040 values are given.
}

of around $38.5 \%$, according to the impact assessment, including the installation of additional PV capacities between 325 and $375 \mathrm{GW}$ in the time frame 2020-2030 [29]. Thus, to achieve this goal, the PV market volume in the EU would have to grow between three to five times compared to 2020 levels. However, these numbers could double if the electricity demand rises faster than what current projections indicate [30].

Despite the COVID-19 pandemic, preliminary data show that the annual market continued its moderate growth in the European Union (EU27) to about 18.2 GW in 2020. The top three countries were Germany (5.0-5.2 GW), the Netherlands (2.9-3.1 GW) and Spain (2.5-2.7 GW). A newcomer in the GW markets is Poland, which installed between 1.6 and $1.8 \mathrm{GW}$. Five more countries installed more than 500 MW in the year 2020, namely Belgium, France, Hungary, Italy and Portugal.

\section{Conclusions}

Currently, solar photovoltaic electricity generation is often the lowest cost generation source and the number of countries where this holds true is growing. This reality coupled with significant potential for further cost reduction will drive the growth of PV installations in the coming decades. Various PV industry associations, non-governmental organisations (NGO), like Greenpeace, the Energy Watch Group, Bloomberg New Energy Finance (BNEF), the International Energy Agency as well as the International Renewable Energy Agency (IRENA), have developed scenarios for the future growth of PV systems [1,31-36]. The different deployment figures of these scenarios are shown in Table 1. Between 2016 and 2020, the predicted PV capacity in the IEA World Energy Outlook has significantly increased. Pre 2015 scenarios can be found in the JRC PV Status Reports $[37,38]$.

It is interesting to note that in 2020 some of the scenario numbers were already exceeded (red figures).

All scenarios show vast growth potentials for PV power in the future, regardless of the existing differences in the deployment pathways and ambitions. To supply the 2019 global electricity generation of $26942 \mathrm{TWh}$ with solar PV would require about $19500 \mathrm{GW}$ of PV capacity and approximately $0.3 \%$ of the world's land area would be required. Various studies have shown that vast unused generation potentials exist on rooftops, facades, dual use of infrastructure, brownfield or novel applications like agriphotovoltaics or floating PV systems [22,39-43].

Key to all is an enabling policy framework and the support of all stakeholders. No fundamental system change needed for the energy transition, including the massive deployment of solar, will happen by itself. To stay on track for a maximum of $1.5^{\circ} \mathrm{C}$ global temperature increase, our societies have to acknowledge the need of an accelerated energy transition towards a netzero carbon energy supply by 2050. Solar photovoltaics is a crucial pillar to achieve this due its very low (based on a full life cycle analysis) $\mathrm{CO}_{2}$ footprint, its modularity, and its "no emission no pollution" function that make it a perfect solution for a dense urban environment [44]. The number of barriers ranging from perception, legal and regulatory conditions as well as technical limitations of the existing transmission and distribution systems is still high. So far, neither the political will to accelerate the use of renewable energy sources such as PV nor the necessary adaptation and transformation of the energy networks is in line with the urgency to decarbonise our energy supply by 2050 . 


\section{Disclaimer}

The views expressed are based on the current information available to the author and may not in any circumstances be regarded as stating an official or policy position of the European Commission.

\section{References}

1. International Energy Agency, World Energy Outlook (IAEA, 2020)

2. International Energy Agency, Executive summary - World Energy Outlook, October 2020. https://www.iea.org/ reports/world-energy-outlook-2020

3. D. Bogdanov, J. Farfan, K. Sadovskaia et al., Radical transformation pathway towards sustainable electricity via evolutionary steps, Nat. Commun. 10, 1077 (2019)

4. M.Z. Jacobson et al., 100\% Clean and renewable wind, water, and sunlight all-sector energy roadmaps for 139 countries of the world, Joule 1, 108 (2017)

5. D. Bogdanov, A. Gulagi, M. Fasihi, C. Breyer, Full energy sector transition towards $100 \%$ renewable energy supply: integrating power, heat, transport and industry sectors including desalination, Appl. Energy 283, 116273 (2021)

6. A. Jäger-Waldau, Snapshot of photovoltaics - february 2018, EPJ Photovoltaics 9, 6 (2018)

7. Bloomberg new Energy Finance, Solar PV trade and manufacturing - a deep dive, 2021

8. P.P. Altermatt et al., Requirements of the Paris Climate Agreement for the coming 10566 years on investments, technical roadmap, and expansion of PV manufacturing, in: 37th 567 European Photovoltaic Solar Energy Conference and Exhibition, 2020, pp. 1999-2004

9. M. Victoria et al., Solar photovoltaics is ready to power a sustainable future, Joule 5 (2020); https://doi.org/10.1016/j. joule.2021.03.005

10. International Technology Roadmap for Photovoltaic (ITRPV) (2019 Results, 11th Edition, October 2020)

11. Bloomberg New Energy Finance, 2H 2020 LCOE update, 2020

12. S. Comello, S. Reichelstein, The emergence of cost effective battery storage, Nat. Commun. 10, 2038 (2019)

13. IHS Press Release, Global energy storage installations to more than double year on year in 2021, 2021

14. E. Vartiainen, G. Masson, C. Breyer, D. Moser, E. Román Medina, Impact of weighted average cost of capital, capital expenditure, and other parameters on future utility-scale PV levelised cost of electricity, Prog. Photovolt. Res. Appl. 28, 439 (2019)

15. Bloomberg New Energy Finance, Energy Transition Investment Trends, 2021

16. IHS Press Release, IHS Markit releases new 2020 solar installation forecast in light of the impact of coronavirus (COVID-19), 2020

17. Bloomberg New Energy Finance, 1Q 2021 Global PV Market Outlook, 2021

18. European Photovoltaic Industry Association, Global Market Outlook for Photovoltaics, various years

19. Solar Power Europe, Global Market Outlook for Photovoltaics, various years
20. IEA PVPS, Snapshots of Global PV Markets and Trend Reports

21. Photovoltaic Energy Barometer, Systèmes Solaires, le journal du photovoltaique

22. R. Gonzalez Sanchez et al., Assessment of floating solar photovoltaics potential in existing hydropower reservoirs in Africa, Renew. Energy 169, 687 (2021)

23. World Bank, Scaling Solar Programme. https://www. scalingsolar.org/

24. P. Ferrera, Dessert-to-Power: The Sahel seeks to harness the sun, Atalayar, 2021. https://atalayar.com/en/content/des ert-power\%E2\%80\%9D-sahel-seeks-harness-sun\%C2\%A0\% $\mathrm{C} 2 \% \mathrm{~A} 0$

25. New and Renewable Energy Authority (NREA), Benban 1.8 GW PV Solar Park, Egypt, Strategic environmental \& social assessment - Final report, 2016. https://www.eib.org/ attachments/registers/65771943.pdf

26. 国家能源局(National Energy Administration),2020年全社会 用电量同比增长 $3.1 \%$, 2021. http://www.nea.gov.cn/202101/20/c 139682386.htm

27. European Commission, The European Green Deal. vol. Communicat. Brussels, Belgium, 2019

28. European Commission, Impact Assessment on Stepping up Europe's 2030 climate ambition Investing in a climate-neutral future for the benefit of our people, Brussels, Belgium, 2020

29. A. Jäger-Waldau, I. Kougias, N. Taylor, C. Thiel, How photovoltaics can contribute to GHG emission reductions of $55 \%$ in the EU by 2030, Renew. Sustain. Energy Rev. 126, $109836(2020)$

30. I. Kougias, G. Kakoulaki, N. Taylor, A. Jäger-Waldau, The role of photovoltaics for the European Green Deal and the recovery plan, Renew. Sustain. Energy Rev. 144, 111017 (2021)

31. Greenpeace International, European Renewable Energy Council (EREC), Global Wind Energy Council (GWEC), Energy [r] evolution, 5th edition 2015 world energy scenario, 2015. http://www.greenpeace.org/international/en/publica tions/Campaign-reports/Climate-Reports/Energy-Revolu tion-2015

32. M. Ram et al., Global Energy System based on $100 \%$ Renewable Energy - Power Sector, Study by Lappeenranta University of Technology and Energy Watch Group, Lappeenranta, Berlin, 2017

33. M. Ram et al., Global energy system based on $100 \%$ renewable energy - power, heat, transport and desalination sectors, Study by Lappeenranta University of Technology and Energy Watch Group, Lappeenranta, Berlin, 2019

34. Bloomberg New Energy Finance, New Energy Outlook 2020, 2020

35. IRENA, Global energy transformation: a roadmap to 2050 (IRENA, 2019)

36. International Energy Agency, World Energy Outlook 2016 (IEA, 2016)

37. A. Jäger-Waldau, PV status report 2013, Publications Office of the European Union, 2013

38. A. Jäger-Waldau, PV Status Report 2014, Publications Office of the European Union, 2014

39. P. Gagnon et al., Rooftop Solar Photovoltaic Technical Potential in the United States: A Detailed Assessment (NREL, 2016)

40. K. Bódis et al., A high-resolution geospatial assessment of the rooftop solar photovoltaic potential in the European Union, Renew. Sustain. Energy Rev. 114, 109309 (2019) 
41. A. Jäger-Waldau, The untapped area potential for photovoltaic power in the European Union, Clean Technol. 2, 440 (2020)

42. N. Lee, U. Grunwald, E. Rosenlieb, H. Mirletz, A. Aznar, R. Spencer, S. Cox, Hybrid floating solar photovoltaicshydropower systems: benefits and global assessment of technical potential, Renew. Energy 162, 1415 (2020)
43. J. Farfan, C. Breyer, Combining floating solar photovoltaic power plants and hydropower reservoirs: a virtual battery of great global potential, Energy Procedia 155, 403 (2018)

44. M. Pehl et al., Understanding future emissions from lowcarbon power systems by integration of life-cycle assessment and integrated energy modelling, Nat. Energy 2, 939 (2017)

Cite this article as: Arnulf Jäger-Waldau, Snapshot of photovoltaics - March 2021, EPJ Photovoltaics 12, 2 (2021) 